\title{
ПЕРЕКЯАДИ КИТАЙСЬКОЇ ЯІТЕРАТУРИ
}

ISSN 2616-7328 (Online), ISSN 2409-904X (Print)

Kitaêznavčì doslìdžennâ, 2021, No. 4, pp. 146-165

DOI: https://doi.org/10.51198/chinesest2021.04.146

UDC 82

\section{XIA YAN. THE FASCIST BACILLUS}

\section{O. Vorobei}

$\mathrm{PhD}$ (Philology), Associate Professor

at Department of Far Eastern and Southeastern Languages and Literatures, Institute of Philology, Taras Shevchenko National University of Kyiv

14, Taras Shevchenko Blvd,

01601, Kyiv, Ukraine

oerjia@gmail.com

The oeuvre of Xia Yan (夏衍, 1900-1995), a Chinese playwright, writer, journalist, screenwriter and stage director, had a significant impact on history of modern Chinese drama: his unique type of dramatic art marked a new stage in the development of Chinese drama. Xia Yan is often called "a peer of the XX $\mathrm{X}^{\text {th }}$ century", who travelled a peculiar life and creative journey. The themes of the works by Xia Yan always met the public needs: the author used to keep in touch both with intellectuals and ordinary people. He was cognizant of the Chinese outlook and public sentiments; thus, his dramas usually rendered his vision of the causes of the socio-economic crises, and his characters transmitted potential solutions to the problems. "The Fascist Bacillus" by Xia Yan discusses the spread of the idea of fascism in the world, which was relevant in the early '40s. The playwright describes the life of a bacteriologist who consciously lives a sheltered life and strives to be engaged in research. Consequently, over ten years, he was escaping from war by constantly changing a place of residence and attempting to separate science from politics. As a result, the scientist found himself in occupied Hong Kong, in which Japanese looters barged into his house and killed each other during the reckless arbitrariness and under the influence of uncontrolled aggression. Having suffered the severe trauma of losing a loved one, Professor Yu realized that it is impossible to hide from the fascist bacillus, which has spread to almost all countries, it must be resolutely fought.

Although Xia Yan's play demonstrates an out-of-the-box solution of relations between science and politics in the middle of the XXth century, it hasn't lost its imagery, strength and relevance. Therefore, the spiritual decline of Professor Yu's friend, Zhao Antao, reminds a modern reader that even adherence to subjectively correct ideological principles will never guarantee the preservation of moral virtues.

(C) 2021 O. Vorobei; Published by the A. Yu. Krymskyi Institute of Oriental Studies, NAS of Ukraine and the Ukrainian Association of Sinologists on behalf of The Chinese Studies. This is an Open Access article distributed under the terms of the Creative Commons Attribution License (https://creativecommons.org/licenses/by-nc-nd/4.0/). 
"The Fascist Bacillus" is a play about the relations between politics and science in which the playwright leads a reader to the obviously disappointing idea that science will never be ideologically independent and serve its higher purposes - it will be constantly dependent on public opinion and political perturbations. Xia Yan was confident that scientific advances would be able to bring undeniable benefits to humanity only if scientists are politically aware and, at the same time, non-partisan.

Keywords: drama, Xia Yan, politics, science, interrelation.

\section{СЯ ЯНЬ. БАЦИЛИ ФАШИЗМУ}

\section{О. С. Воробей}

Творчість китайського драматурга, журналіста, сценариста й режисера Ся Яня (夏衍, 1900-1995) справила значний вплив на історію сучасної китайської драми: його винятковий тип драматичного мистецтва знаменував новий етап у розвитку китайської драматичної літератури. Ся Яня часто називають однолітком XX століття, що пройшов унікальний життєвий і творчий шлях. Тематика творів Ся Яня завжди відповідала потребам суспільства: автор постійно підтримував зв'язок як 3 представниками інтелігенції, так і з простим народом. Він завжди добре розумів світовідчуття китайців та настрої суспільства, тому часто у п'єсах він подавав власне бачення причин соціально-економічних криз, а в уста своїх персонажів вкладав можливі варіанти вирішення цих проблем. П’єса Ся Яня «Бацили фашизму» розкриває тематику поширення ідей фашизму у світі, яка була актуальною на початку 40-х років XX ст. Драматург змальовує життя вченого-бактеріолога, який свідомо усамітнюється від навколишньої дійсності, прагне займатися лише науковими дослідженнями. Протягом десяти років він тікає від війни, постійно змінюючи місце проживання й намагаючись відмежувати науку від політики. Зрештою, вчений опиняється в окупованому Гонконзі, де японські мародери вриваються в його будинок і під час нестримного свавілля та у стані неконтрольованої агресії вбивають друга. Отримавши важку травму втрати близької людини, професор Юй усвідомлює, що від фашистської чуми, яка поширилася майже всіма країнами, уже не сховатися, 3 нею необхідно рішуче боротися.

Хоча у п’єсі «Бацили фашизму» Ся Янь демонструє готове рішення взаємин між наукою і політикою середини XX ст., однак п'єса жодною мірою не втратила своєї образності, насиченості та актуальності. Духовна деградація друга професора Юй Чжао Аньтао - слугує нагадуванням сучасному читачеві про те, що навіть дотримання суб'єктивно правильних ідеологічних принципів ніколи не стане гарантією збереження моральних чеснот.

«Бацили фашизму» - п’єса про взаємозв'язок політики та науки, в якій драматург підводить читача до очевидно невтішної думки про те, що наука ніколи не зможе залишатися ідеологічно незалежною і служити своїм вищим цілям, вона постійно буде залежати від громадської думки та політичних пертурбацій. Ся Янь упевнений, що наукові досягнення принесуть беззаперечну користь людству тільки в тому випадку, коли вчені будуть політично обізнаними, але водночас незаангажованими.

Ключові слова: драма, Ся Янь, політика, наука, взаємозв'язок. 


\section{Ся Янь \\ БАЦИЛИ ФАШИЗМУ ${ }^{1}$ \\ (n'єса у n'яти діяx)}

Юй Шифу - доктор медицини.

Дійові особи

Шицзуку - його дружина.

Суміко (Шоучжень) - його донька.

Чжао Аньтао - друг та краянин Юй Шифу.

Цінь Чжен’'і - друг та краянин Юй Шифу.

Молочник.

Сусідка.

Цянь Ціньсянь (Люсі) - дружина Чжао Аньтао.

Цянь Юй - молодший брат Цянь Ціньсян.

Сюй А’фа - водій.

Матінка Чжан - служниця.

Дженні Ма - дівчина Цянь Юя.

Директор Цзінь

Пан $\mathrm{C}$

А Чао

торговці.

А Мей - служниця.

Японський солдат один, два, три.

Yac:

З осені 1931 до весни 1942.

\section{Мicце:}

Токіо, Шанхай, Гонконг, Гуйлінь.

Кінець грудня 1941 p.

\section{ДІя 4}

Квартира Юй Шифу в Гонконгу.

Квартира в районі середнього класу неподалік від іподрому «Хеппі веллі», другий поверх. Праворуч - двері, що ведуть на сходи, у правому куті сцени розташовані двері у внутрішню кімнату та вбиральню; по центру, за залізним каркасом - велике вікно зі скляними дверима, за якими розташований невеличкий балкон, з його висоти можна спостерігати за бурхливим вуличним потоком людей і машин; ліворуч - двері в коридор. Кімната на сцені - «храм науки Юй Шифу» - його кабінет, лабораторія. Це те місце, де в перестанках між роботою він бавиться й жартує із Шоучжень та слухає гру Цянь Юя на скрипці.

Праворуч розташовані два давнішні дивани, чайний столик, а біля вікна - його великий письмовий стіл, на якому все заставлено вщент: тут і пробірки, закриті ватними тампонами, і скляна посудина для зберігання медичної гіроскопічної вати, і чашкові ваги, i Binocular dissecting microscope (бінокулярний мікроскоп),

1 Перекладено за виданням 上海屋檐下; 法西斯细菌 / 夏衍箸 北京: 人民文学出版 社, 2007.9. 
що приваблює до себе всі погляди. Поруч зі столом - велика шафа, яка виконує роль як книжкової полиці, так і медичної шафи: тут хаотично розставлені різноманітні за формою та виглядом аптечні склянки, пробірки, колби, а також більшою мірою книжки європейськими мовами та всілякі західні журнали.

На стіні, окрім портрета Едварда Дженнера ще з тих часів, коли вони жили в Токіо, також висять діаграми, таблиці та збільшені зображення різних мікроорганізмів. На вікні хаотично навхрест розклеєний веленевий папір: під час війни в Гонконгу це стало загальноприйнятою тимчасовою мірою, щоб уберегти вікна від розколів і тріщин. Лампу огортає бавовняна тканина синього кольору: це ще залишилося 3 тих часів, коли потрібно було контролювати рівень освітлення під час експериментів. Фактично, коли хвилі війни докотилися до Гонконгу, постачання води та електроенергії відразу припинилося.

\section{Сцена 1}

Двадцять п'яте грудня, безхмарне надвечір'я. Зазвичай це сезон снігопадів, однак на півдні країни, у Гонконгу, це більше нагадує ранню весну: яскраві сонячні промені наповнили світлом вікно, навхрест обклеєне папером; приблизно четверта година дня.

Завіса опущена, чути запальні протяжні звуки бомбування. За структурою звучання їх умовно можна розділити на три види. Перші - це гарматні вистріли, услід за ними - бах-бах - рвуть повітря постріли артилерії, і насамкінець снаряди катапульт розривають ущент свої намічені цілі.

Завіса піднімається, на сцені темно, невпинно чути звуки артилерійського обстрілу. Один постріл влучив у сусідній будинок, після вибуху пролунав характерний звук розбитого скла та розтрощеної цегли.

Коли вмикається світло (якраз після звуків розбитого скла сусіднього будинку), змарніла на вигляд Шицзуку тягне за руку Юй Шифу, намагаючись усадити його на диван у кутку кімнати. Ї̈̈ червоні очі свідчать про хронічну втомленість і недосипання, волосся закудлане, як ніколи раніше.

Юй Шифу, як і до цього, одягнений у білий медичний халат, на вигляд також дуже втомлений.

Шицзуку. (тяжко дихаючи) Посидь ось тут, це сліпа зона!

Юй Шифу дивиться на неї, рукою кличе ї̈ сісти поруч.

Шицзуку забилась у куток.

Звук гармат. Чути - бах! Обоє відразу закривають вуха руками.

Дочекавщись, коли звуки бомбування стихають, вони, перевівши подих, відводять руки.

Шицзуку. (жаліючись) Казала ж тобі, давай переховаємося в бомбосховищі, так ти ж-ні, це все ти... (Не продовжує думку.)

Юй Шифу. (насупившись) Там важке й затхле повітря, якщо довго там залишатися, можна захворіти!

Шицзуку. (заперечуючи) Захворіти, вочевидь, за смерть від гарматного пострілу... (Хоче продовжити, але зупиняється, витримує паузу, уважно 
дивиться на чоловіка, благаючи.) Я ж не заради себе й Шоучжень, ти маєш подумати про себе; задля своїх досліджень - ти зобов'язаний себе зберегти! Якщо в тебе якісь упередження, тоді дозволь нам... (Ковтаючи сльози.)

Юй Шифу. (Мовчки пестить свою дружину по плечу, втішаючи ї̈, за деякий час раптом наче щось згадав.) Шоучжень...

Шицзуку. Разом з молодшим Юєм, у бомбосховищі.

Юй Шифу. Ти їй наділа марлеву пов’язку?

Шиизуку киває.

Юй Шифу. Дала щось із собою поїсти?

Шицзуку. Молодший Юй узяв трохи печива.

Юй Шифу заспокоєно киває, рукою тягнеться до чайного столика налити собі води, однак глечик виявляється порожнім.

Шицзуку. Сиди, я тобі принесу. (Встає, але, зробивщи два кроки й саме збираючись відчинити двері, щоб зайти до внутрішніх покоїв, знову чує гарматний залп. Юй Шифу схоплюється і прудко відтягує ї̈ назад.)

Юй Шифу. Не йди, я не хочу пити.

Шицзуку. (нарікаючи) Коли ми їхали із Шанхаю до Гонконгу, всі правили те саме: війна до Гонконгу ніколи не дійде, але...

Юй Шифу. (не звернувщи уваги на ї̈ слова) Японці наче справді сказилися... (Затинається.)

\section{Шицзуку схиляе голову.}

Юй Шифу. (Мовчки легенько плескає ї̈ по плечу, витримавщи паузу, говорить.) Ти...

Шицзуку. (наче сама до себе) Як же ж нам далі бути, води у крані немає, дров теж немає, рису не купиш, овочі - теж не знайдеш. Сьогодні вже вісімнадцятий день бомбування, якщо місто справді збираються боронити три місяці, на що ж перетвориться Гонконг...

Юй Шифу. Три місяці?

Шицзуку. Так пишуть у газетах, оборона Гонконгу розрахована приблизно на три місяці.

Tuma.

Юй Шифу здається дуже втомленим, рукою масує своє чоло, відкинувшись на спинку дивана.

Шицзуку. Що таке? Ти...

Юй Шифу. (тихо) Щось... паморочиться в голові.

Шицзуку. (провівщи рукою по його чолу) Ти занадто змучений... Усе правильно, ти ж не їв... Коли трохи вщухнуть постріли, я принесу тобі води. (Прудко встає, штовхає двері, щзо ведуть до внутрішньої кімнати, заходить, чути лише голос.) А Мей! А Мей! 
Збадьорений Юй Шифу знову сідає. Шиизуку приносить маленьку мисочку печива, ставить перед ним.

Шицзуку. Води немає ані краплі...

Юй Шифу. Де А Мей?

Шицзуку. Напевно, ховається десь унизу. Сиди, не вставай! (Знову квапливо заходить до внутрішньої кімнати.)

Юй Шифу з '̈в одне печиво. Гарматні постріли повністю затихли. Він підводиться, ступає два кроки, несвідомо підходить до свого столу; узявши до рук пробірку, розглядає їі. Почувщи кроки Шицзуку, швидко повертається на своє місче, заплющивщи очі, робить вигляд, щуо відпочиває.

Шиизуку, здогадавшись, щзо він уставав, гірко посміхається й передає йому маленьку чашку води.

Юй Шифу. (спрагло осушив чашку, дивиться на Шищзуку) Коли не стріляють... теж сидіти тут?

\section{Шиизуку киває.}

Юй Шифу, вочевидь, незгодний, але не в змозі говорити.

На сходах чути чиїсь кроки, стукіт у двері, Шицзуку схвильовано біжить до дверей. Спочатку відхиляє тканину синього кольору, що прикриває невеличке віконце на дверях, $і$ лише потім відчиняє їх.

Заходить Цянь Юй із термосом та ковдрою під рукою і Шоучжень з невеличкою листівкою та журналом.

Шицзуку. Чому повернулися? Я саме збиралася відправити вам обід.

Цянь Юй. (насупивши брови) Це просто нестерпно, сьогодні ввечері, хоч би що, але я сплю вдома!

Шоучжень. (впустивши з рук усі свої речі, підлітає до батька) Тату, а ти чому не прийшов?

Юй Шифу. (ніжно посміхаючись, пестить ї̈, потім звертається до неї голосом, наче на допиті) Ти не вдягала марлеву пов'язку?

Шоучжень. (дурненько посміхаючись) Вдягала.

Юй Шифу. (із суворим виразом обличчя) Діти не повинні обманювати.

Шоучжень. (усе ще посміхаючись, розпещено надуває губки) А як же ж їсти печиво в пов'язці?

Шицзуку. (до Цянь Юя) Ти не бачив А Мей?

Цянь Юй. (знімаючи вовняну камізельку) Унизу під сходами, налякана до смерті. Води немає?

Шицзуку. Ані краплі.

Цянь Юй. Я сам сходжу наберу у криниці (Виходить через двері до внутрішніх покоїв.)

Шицзуку. (услід) Обережно! Зачекав би, поки А Мей принесе. (Дає Шоучжень печиво, яке не доїв Юй Шифу.) 
Шоучжень. (запхнувши печиво до рота, розмовляє, розжовуючи його) Мам, дитина народилася!

Шицзуку. Що?

Шоучжень. У бомбосховищі одна дівчина народила дитину.

Шицзуку. Справді?

Шоучжень. (збуджено й радісно розмахуючи руками) Дуже швидко, не минуло й чверті години. Кажуть, немовля дуже велике.

Шицзуку. (засуджуючи) I ти ходила подивитися?

Шоучжень. Нi.

Шицзуку. Доки постріли вщухли, я піду приготую вам попоїсти, а то ввечері знову почнуть бомбувати.

\section{Коли Шиизуку підходить до дверей, заходить Цянь Юй, витираючи рукою лице.}

Цянь Юй. Сьогодні після обіду наче й безперестану, трясця, навіть на Різдво не вгамуються.

Шищзуку. (повернувши голову) Різдво? А, все правильно, сьогодні ж 25 число. (Раптом щзось згадавии, розвертається, ставить невеличкий ослінчик поруч із диваном, де сидить Юй Шифу, притягнувши за руку Шоучжень, усаджує іï.) Посидь тут, порозважай батька, а мама піде приготує вам попоїсти. (командним голосом) Наглянь за ним, не дозволяй вставати. (Побачивши насуплені брови Юй Шифу, дає йому журнал, який принесла Шоучжень.) А ти посидь, почитай. Брате Юй, ти теж іди сюди, тут - сліпа зона.

Цянь Юй. (кивнувши, сідає; узявши з мисочки печиво, бачить, що там більше нічого не залишилося, до Шиизуку) Ще є?

Шицзуку. Уже немає, зачекайте, я піду щось приготую. (Виходить).

Цянь Юй. (сам до себе) Якось дивно: щойно почалася війна, усім до жаги приспіло смачно поїсти. I що ілюзорнішою стає можливість купити той самий рис, то більше хочеться їсти. У бомбосховищі всі - від малого до старого квилять від голоду. Пане Юй, що це за явище з погляду фізіології? (неспод $i$ вано щось згадавши, не дочекавшись його відповіді, хутко продовжує) Точно, ледве не забув, гортаючи журнали в бомбосховищі, прочитав одну новину...

Юй Шифу гортає ілюстрований журнал Шоучжень, не звертає уваги.

Цянь Юй. Це вас стосується (підбігає до щзойно принесеної ним ковдри $i$ 3-під неї дістає журнал із червоною палітуркою). Це стосується нового відкриття у сфері тифозних захворювань...

Юй Шифу. (заиікавлено) Що?

Цянь Юй. (гортаючи журнал) Ви, здається, часто згадували ім'я одного відомого бактеріолога - Hans Zinsser? Торік він поїхав на Далекий Схід, подорожував Китаєм, Японією, а ще побував у Бейпіні², де три місяці пробув гостьовим професором у лікарні при об'єднаному медичному коледжі.

Юй Шифу. Це я знаю...

\footnotetext{
${ }^{2}$ Назва м. Пекін з 1928 р. до 1949 р. (Тут і далі примітки перекладачки.)
} 
Цянь Юй. Ага, коли він повернувся, то в місячнику “The Atlantic” надрукував автобіографічну статтю «Правдивіше за поезію». Він, певно, був поетом.

Юй Шифу. І який це стосунок має до тифу?

Цянь Юй. Стривайте. Після всіх його подорожей він підтвердив одну свою теорію - про зв'язок тифу з політикою.

Юй Шифу. Що?

Цянь Юй. Він стверджує, що інфекційні хвороби й війна - це нероздільні, єдиноутробні сестри; за війною завжди слідують тиф, холера та решта інфекційних захворювань...

Юй Шифу. Про це вже й так раніше говорили.

Цянь Юй. Ви це вже знали? Ну добре, останній абзац його статті написаний дуже влучно, я вам зачитаю (розгортає журнал, читає): «Тиф іще не схилив коліна, можливо, він розповсюджуватиметься кілька століть поспіль, лише тупість і варварство людей дають йому можливість і надалі існувати». Тупість і варварство - це він має на увазі жорстокі війни. «Але межі його поширення стають дедалі меншими, і скоро їх можна буде посадити під замок, як диких звірів у зоопарку». Ну як? Ці слова...

Юй Шифу киває, простягнувши руку по журнал.

Цянь Юй. Але тут його міркування зазнали фіаско, ці тифозні дикі звірі, розбивши вщент клітку в зоопарку, зможуть добратися до нас.

\section{Юй Шифу мовчить.}

Цянь Юй. А тому його треба знищити дощенту, фашизм обов'язково треба винищити...

Юй Шифу. (посміхнувшись, жестом руки припиняє його роздуми) Досить, досить, бачу, ти грунтовно підгодувався агітувати мене.

Цянь Юй. (щиро сміється) Ну добре, не будемо про це, поговоримо про медицину.

Юй Шифу. Медицину? Гаразд, починай.

Цянь Юй. Ви знаєте, яка у світі зараз найлютіша бацила з-поміж усіх?

Юй Шифу. (остовпівши) Що?

Цянь Юй. 3 липня цього року й дотепер у Східній Європі, на лінії фронту Німеччини та СРСР, вона вже загубила мільйони людей, хоча насправді ця зараза вже давно поширюється у світі...

Юй Шифу. (сумніваючись) Що ж це за хвороба?

Цянь Юй. Поширюють цю бацилу аж ніяк не щури, пацюки, і не воші 3 блохами, а ми самі - люди. Ця бацила паразитує в мозку людей, за тифозні бактерії вона менша в сотні разів - і під мікроскопом із шістсоткратним збільшенням iï не розгледіти, iї не можна культивувати, це... це умоглядні бацили.

Юй Шифу. А ти все жартуєш, несеш якусь нісенітницю.

Цянь Юй. (не зважсаючи на нього, продовжує) Ім'я цієї бацили - “fascismo", що в перекладі означає «фашизм», саме ця бацила стала причиною такого інфекційного захворювання, як фашистська окупація... 
Юй Шифу. (сміється) О, звучить розумно, а коли це ти почав будувати свою теорію?

Цянь Юй. (самозадоволено посміхаючись) Учора ввечері в бомбосховищі було дуже холодно, я свій верхній одяг віддав Шоучжень, а сам не міг заснути від холоду. І так, міркуючи про все на світі, я подумав, що всі люди, які туляться тут, у бомбосховищі, - i жінки, і чоловіки, дітлахи і старі - усі вони вражені бацилами фашизму...

Юй Шифу. (nідіймаючись, починає ходити) О, непогана ідея, досить розумно. Однак ця бацила медично не виліковна.

Шоучжень. (грає на губній гармошиі, повернувщи голову, бачить, що іï тато відійшов від свого місия, кричить) Тату! Мама сказала, щоб ти сидів на місці!

Юй Шифу, кволо посміхаючись, сідає на своє місие.

Цянь Юй. (обережно проходить, знімає зі стіни свою скрипку) Виходить, ми їй можемо дозволити й надалі поширюватися?..

Юй Шифу. Я й не це мав на увазі.

Цієї миті з внутрішньої кімнати заходить служниия А Мей, ї̈ обличчя спотворила гримаса паніки. Ані пари з вуст, підбігає подивитися на щось до вікна, ні жива ні мертва чимдуж біжить назад.

Цянь Юй. Що сталося?

А Мей. Япошки!

Цянь Юй. (здивовано) Де?

А Мей, тремтячи, підходить до вікна, пальцем указує на гору навпроти $i$ знову сполошено вибігає в задні двері.

Цянь Юй. (вдивляючись) Де, нічого немає, якісь дурниці (несподівано) О, справді... (Повернувши голову, відсторонив Шоучжень, виглядає пригнічено.) А це не занадто близько?

Юй Шифу. Де?

Цянь Юй. Це ж там гора Камерона, а обігнувши іiі, - вже й район іподрому...

Шицзуку. (тяжко дихаючи, вбігла) Справді? Побачили?

Цянь Юй. Невеличкий загін на декілька десятків осіб, гм-м, а ще й кавалерія...

Шицзуку хоче підбігти подивитися, але десь недалеко чути постріли кулемета. Вона прудко відтягує Цянь Юя і ховає його у сліпій зоні. Tима.

Шицзуку. (тихо до Цянь Юя) А той район біля гори, де вулиця Блакитних басейнів, начебто вже здали ворогові?

Цянь Юй. Так, ви не знаєте, куди могла втекти моя сестра з чоловіком? 
Шицзуку. А панночка Ма з ними?

Цянь Юй. Учора повернулася у Ваньчай ${ }^{3}$.

Шицзуку. (до Юй Шифу, повністю розгублена) Ти краще переховайся в лікарні, якщо вони справді прийдуть.

Цянь Юй. А вони наче вже не прийшли? Які ще сумніви.

Юй Шифу. (хитає головою) А є різниця...

Шицзуку. $€$, у лікарні буде безпечніше, за всіма правилами, під час війни лікарні завжди могли...

Цянь Юй. (щвидко) За всіма правилами? Ці японські нелюди ніколи не дотримувалися жодних правил. (Знову підбігає до вікна.)

\section{Шиизуку наче вдарило, мовчить.}

Юй Шифу. А ви?

Шицзуку. Шоучжень піде разом з тобою...

Під час їхньої розмови вибухнув скажений стукіт у двері. Усі сполотніли зі страху, Шоучжень ось-ось розплачеться.

Цянь Юй. (до Шицзуку та Шоучжень) Мерщій до внутрішньої кімнати! (Обох заштовхує до вбиральні, замикає двері, повертається до вхідних дверей, піднімає шторку подивитися й одразу хутко відчиняє двері.)

Сполошено заходить Цянь Ціньсянь - зі скошлаченим волоссям і брудним обличчям, одягнена в обмарпаний одяг, який колись давно в Кантоні носили служниці.

Цянь Ціньсянь. Швидше, швидше, допоможіть підвести! (дивиться назад).

Юй Шифу. Що сталося? (Підбігає.)

Цянь Юй вибігає за двері. Шиизуку та Шоучжень виходять.

Цянь Ціньсянь. Він... знепритомнів... Аньтао... біля воріт.

Шицзуку. Як же ж так, швидше заходьте...

Цянь Юй та Цінь Чжен'ї під руки заводять Чжао Аньтао, обидва заросли бородою та вусами, одяг у жахливому стані. Цінь Чжен' $і$, підвівши та всадивши Чжао Аньтао на диван, переводить подих.

Цінь Чжен'ї. Дайте йому склянку води... Він виснажений, а ще й розхвилювався.

Шицзуку. (прудко налила склянку води) Як же ж так...

Юй Шифу. (узявши склянку води, підносить до його рота) Легше, легше, ти...

3 Один 318 округів Гонконгу. Розташований у центрі північної частини острова Гонконг. 
Чжао Аньтао. (побачивши Юй Шифу, упершись у нього поглядом, кричить) Кінець! Усьому кінець...

Юй Шифу. (заспокоює його) Не рухайся, не рухайся. (Схвильовано міряе йому пульс.) Тобі не треба нервувати, заспокойся.

Цянь Ціньсянь. Ой, жах, налякав до смерті.

Чжао Аньтао. (продовжує кричати) Нічого немає, гроші, заощадження усьому кінець... Я банкрут, нічого немає...

Цянь Ціньсянь. (плачучи) Не кричи, сенсу від твоїх криків жодного.

Цінь Чжен'ї. Та нічого дивного, на ногах кілька днів поспіль, без відпочинку, так, зараз вже нічого не залишилося. Захопивши вулицю Блакитних басейнів, дісталися до готелю у Ваньчай - усе винесли...

Цянь Юй. Що? Вони вже захопили Ваньчай?..

Цінь Чжен'ї. Та ще вчора ввечері все шкереберть, підпалили й розграбували...

Цянь Ціньсянь. Годі, не треба... (Знесилено сідає на диван, істерично запалює циигарку.) Це дратує.

Шицзуку наповнила миску водою, Юй Шифу руками починає витирати йому лице. Вологим рушником проводить по його чолу.

Чжао Аньтао. (вгамувавшись, знову пильно дивиться в очі Юй Шифу, хрипло кричить) Шифу, Шифу, скажи мені, що робити! Нічого не залишилося, нічого... (Двома руками схопившись за голову, плаче.)

Юй Шифу. Ох, тобі треба заспокоїтися, легше...

Цінь Чжен'ї. (niдxодить) Здоров’я треба берегти, його за гроші не купиш! Ти ж знаєш, де життя - там і надія, правда?

\section{Шиизуку наливає води Чжао Аньтао та Цінь Чжен 'i.}

Цянь Ціньсянь. (збудженим голосом) Дякую. (сама до себе) А що - непогано, жодної копійки не залишилося (Кинула недопалок на підлогу, розтерла ногою.) Ох, пані Юй, є щось попоїсти? Він, певно, зголоднів, сьогодні навіть і води не пив...

Шицзуку. Так, я принесу каші...

\section{Знову почулися постріли кулеметів.}

Цянь Юй. (до сестри) Іди сюди, дурна куля може влучити.

Цянь Ціньсянь. (не рухаючись) Та ну іiі, умерти теж непогано, менше страждати буду.

Цінь Чжен'ї. (холодно посміхаючись) Ну що вони там ще стріляють, я ж раніше ще говорив: висадилися на берег, і не треба тут стріляти, усе одно без пуття.

Цянь Юй. А можливо, це китайська армія почала наступати, у газетах же ж писали...

Цінь Чжен'ї. Так швидко? Якщо китайська армія почне наступати, то їм треба спочатку відбити Коулун! 
Шиизуку виносить кілька піал з рідкою камею.

Чжао Аньтао. (несподівано знову підхоплюється й починає кричати) Оххо-хо, молодший $\mathrm{C}$, А Чао, їм теж кінець, неодмінно, неодмінно (Трагічно посміхасться.)

Юй Шифу. (підносить йому кашу) На, випий трохи, не думай про інше.

Цінь Чжен'ї та Цянь Ціньсянь беруть по тарілці.

Шицзуку. (до Шоучжень) Хочеш? (Шоучжень киває.) Іди зі мною. (Хоче вийти.)

Сполохано забігає А Мей.

А Мей. Япошки! Япошки!

Цянь Юй. Де?

А Мей. (показуючи пальцем на внутрімню кімнату) Уже на нашій вулиці, прийшли!

Усі застигли, переводячи погляд один на одного.

Цянь Юй. (до Шицзуку) Вам теж варто перевдягнутися, сховайтеся у внутрішній кімнаті, якщо вони справді прийдуть, вийдете через задній вхід.

Шицзуку. (Тягне за руку Юй Шифу, Шоучжень.) Ходімо...

Стукіт у двері. Цянь Юй підбігає подивитися, повернувши голову, жестом yсіх заспокоює і відчиняє двері. До кімнати заходить Дженні. Щойно вона зайшла, ї̈ всі оточили.

Цянь Юй. Що сталося, ти звідки?

Дженні. (Падає на диван, де щойно сиділа Цянь Ціньсянь, хустинкою витирає краплі поту, на силу говорить.) Кінець!

Цянь Ціньсянь. Що сталося?

Дженні. (незворушно) Кінець, уже не стріляють.

Цянь Юй. Що сталося?

Дженні. Я спеціально забігла вам повідомити: більше не стріляють, гарматні постріли вщухли, навіть із Центрального прибігали і сказали, що було прийнято рішення припинити вогонь.

Цянь Юй. (не ймучи віри) Нi, тож начебто стріляють?..

Дженні. Стріляють?.. То, певне, ти один, хто піде стріляти.

Звук літака, щео пролітає поблизу.

Шицзуку. Невже...

Дженні. Літаки розповсюджують листівки, повідомляючи, щоб припинили вогонь... 
Неочікувано погляди всіх присутніх наповнилися надією.

Дженні. Фух, ось вам і Різдво!

Повна тиша.

За хвилину Цянь Юй починає легенько насвистувати мелодію "Auld Long Sупе”. Шоучжень підбирає губну гармошку, тихенько підігрує йому.

Юй Шифу. (Повільно підіймається, зі стражденним виразом обличчя.) Ох! (Сповненим болю та жалю жестом руки зупиняє їx.)

Тиша.

\section{Завіса стрімко опускається.}

\section{Сцена 2}

Два дні по тому.

Рано-вранці.

Місце дії те саме.

Не чути жодних кулеметних пострілів чи гарматних залпів, але в повітрі й досі відчувається напруженість і неспокій.

Щойно невибагливо поснідавши, Юй Шифу сидить за письмовим столом, глибоко над чимось задумавшись. А Мей допомагає Шицзуку прибрати після сніданку й віднести все до задньої кімнати. Шицзуку також уже перевдягнулася у старий одяг А Мей. Чжао Аньтао, забившись у подушки на дивані, усе ще очманілими від паніки очима вперся у стелю, плекаючи свої нездійсненні мрії. Цінь Чжен'ї та Цянь Ціньсянь, іще сидячи за обіднім столом, мовчки палять. Цянь Юй та Шоучжень стоять перед вікном, дивлячись на те, що відбувається на вулиці.

За деякий час Цянь Ціньсянь устає й підходить до Чжао Аньтао.

Цянь Ціньсянь. Іди полеж, знову всю ніч не спатимеш.

Цінь Чжен'ї. Хм-м, якось дивно. Коли повсюди стріляли, на диво спалося дуже міцно. Щойно кулемети затихли, сон уже не йде.

Дженні вийшла з вбиральні, із силою розчісує своє довге волосся, вона єдина ще вдягнена у привабливе иііпао.

Дженні. (говорить на ходу) Чому вчора весь вечір били в гонги? Ви чули?

Цінь Чжен'ї. Як же ж не почути.

Цянь Юй. (повернувши голову) Десь били в гонги, сусіди зверху ось били в умивальні тази.

4 Шотландська народна пісня на слова Роберта Бернса, якою в англомовному світі традиційно зустрічають Новий Рік. 
Дженні. Навіщо?

Цінь Чжен'ї. Зараз розграбовують Ваньчай, сусід розповідав, якщо приходять мародери, то б'ють у гонг, немає гонга - у таз, ось так і били весь вечір.

Дженні. Тоді, вочевидь, розграбували все вщент.

Цінь Чжен'ї. I не кажи.

Дженні. (підходить до стільия в лівій частині кімнати й сідає на нього, повернувши голову, гукає Цянь Юя) Підійди!

Цянь Юй. Мг-м? (підходить до неі).

Дженні. (дає йому в руки гарно заплетене в косу пасмо волосся) Потримайно. (Заплітає іншу косу.)

Цянь Юй. (мляво) Ще виряджається!

Дженні. (оманливо наӥвно надуває губки, схиляє голову, тихо) Чом би й ні? Якщо вже вмирати, то гарною.

\section{Цянь Ціньсянь нишком окинула ї̈ поглядом.}

Заходить А Мей з кочиком, підходить до Цянь Юя, обережно щзось запитує.

Цянь Юй. (тихо, але твердо) Не треба.

Цінь Чжен'ї. Що таке?

А Мей. (до Цінь Чжен'ï) Вона говорити, японці й вона поговорити, то і здирства - пфффф.

Цінь Чжен'ї. Правильно! Друже Юй, попроси дружину поговорити з ними. Якщо прийдуть японські солдати, нехай вона вийде й поговорить 3 ними японською... Можливо, так...

Юй Шифу спокійно дивиться на друга, мовчить.

Цінь Чжен'ї. Ну то як? (Уважно дивиться, наче шукає його підтримки та згоди.)

Юй Шифу. (подумавщи, хитає головою) Ти не розумієш іiі, останнім часом вона й так випила немалу чарку горя. Вона не хотіла, щоб хтось знав, що вона японка. I в майбутньому вона також не хотіла 6 торкатися цього питання.

Цінь Чжен'ї. (ревно) Ну, ну чому? Це ж буде зручніше для всіх нас...

Цянь Юй. (niдходить на крок ближче до нього) Зручніше? Ну що ж, давайте скажемо цим японським собакам, що в нас тут японка, і тоді, по-перше, тебе раз за разом будуть допитувати, довго й у найменших дрібницях, i ти будеш переказувати їхню історію сотні разів; по-друге, нюх у японських журналістів ліпший, ніж у кращих дойд, i, як тільки тебе надрукують, одразу навісять ярлик японофіла. Боюсь, пан Юй цього не переживе.

Цінь Чжен'ї. (розуміючи його правоту) Так, це теж не вихід. Однак (хитає головою) ми ж можемо говорити японською, усе ж краще... Агов, друже Чжао, як тобі?

Цянь Ціньсянь. (перебиває його) Ну як йому може бути?! Якщо він розгарячкується, скипить, ще й щось скаже їм, то точно гірше буде! А ти сам не можеш говорити японською?

Цінь Чжен'ї. (відчуваючи себе у скрутному становищі) Hi-ні-ні, я вже все забув, і речення японською не скажу... (розвернувся, говорить наче сам до 
себе) Нi-ні-ні, навіть якщо й можу говорити, то не варто про це і згадувати. Якщо схоплять та зроблять своїм перекладачем, цього я вже не переживу.

У иеей час Дженні, фарбуючи помадою вуста, не втримується й пирскає зі сміху.

Цянь Юй. (до $A$ Мей) Чого стоїш? Іди купи рису!

А Мей, нічого не в змозі заперечити, виходить.

Шоучжень. (діставши губну гармошку, підходить до Цянь Юя) Покажи ще раз, як правильно вигравати?

Цянь Юй. (зі всією серйозністю зупиняє ї̈) Не грай, якщо ці японські собаки почують...

Цянь Ціньсянь. (подививщись на Дженні) Міс Ма, тобі теж треба перевдягнутися, якщо японці увірвуться до кімнати...

Дженні. (заперечуючи) Я вже йду, не хвилюйтесь.

Цянь Юй. Куди?

Дженні. Повертаюсь у Ваньчай.

Цянь Юй. Це ж... Як же ж можна виходити на вулицю! (вказує на вікно) Подивися, на вулицях немає жодної дівчини в ціпао...

Дженні. Мені не страшно.

Цянь Ціньсянь. (гостро, напівсерйозно-напівжартома) Не треба так говорити, якщо тобі не страшно, то нам страшно за тебе. Як уже сталася біда, то всі тримаймося купи, а не...

Дженні. (відверто) Тому я краще піду.

Цянь Юй. (дивлячись у вікно, жестом руки припиняє їхню розмову) Ццц! (Усі стихли.) Хм-м, пане Юй, підійдіть подивіться, унизу троє хворих!

Юй Шифу. Що?

Цянь Юй. Он троє заразних носіїв фашистської бацили!

Юй Шифу подивився, тужливо посміхнувся, мовчить.

Цінь Чжен'ї. (протискається, щзоб подивитися) Ццц! Мовчіть! (тривожно) Вони ж сюди не прийдуть? (Вочевидь, побачив японських солдатів, перевів подих.) Ох, друже Чжао. (Побачивии, що Чжао Аньтао вже майже заснув на дивані, повертається до Юй Шифу.) Друже Юй, цього разу вони щось зовсім до скрути довоювались. А коли ми жили в Токіо, японські солдати ходили величаво, у жовтих мундирах, плащах. А зараз, ох, обдерті-подерті, майже як китайські...

Цянь Юй. Японські солдати, яких ми бачили в Кантоні, набагато охайніші від цих... (махає рукою) Знову двоє... Дідько лисий, ще й із супроводом.

Цянь Ціньсянь, побачивщи, щзо Чжао Аньтао заснув, накрила його покривалом.

Юй Шифу. (питає Цянь Ціньсянь) Сьогодні йому краще? 
Цянь Ціньсянь. (тривожно) Уночі все ще не спить... Щойно заплющує очі, відразу прокидається...

Юй Шифу. Його все це сильно похитнуло, нерви не витримали.

Шоучжень. (дивлячись у вікно) О, це ж (до Цянь Ціньсянь) ваш водій...

Цінь Чжен'ї. (наблизившись) А'фа?

Цянь Ціньсянь. Не може бути, його ж іще раніше схопили японці.

Шоучжень. (пританщьовуючи) Та це точно він, ось уже піднімається.

Підбігає до дверей, посунувши фіранку, дивиться у дверне віконце. Стукіт у двері.

Цянь Ціньсянь. (підходить подивитися) Справді, він (відчиняє двері). Як ти сюди дістався?

До кімнати заходить А'фа, його зовнішній вигляд так само говорить про значні скрути в його житті. У руках тримає маленький вузлик.

Сюй А’фа. (витираючи піт) Пані, яке ж щастя, що я вас знайшов. У вас... усе добре? А як господар?

Цянь Ціньсянь. Заснув, не буди його.

Цінь Чжен'ї. А ти як утік?

Сюй А'фа. (передає клуночок Цянь Ціньсянь) Це тренчкот і декілька сорочок нашого пана, мені пощастило їх витягти з вашого номера на вулиці Блакитних басейнів.

Цянь Ціньсянь. Туди вже можна повертатися?

Сюй А’ фа. Нi, там зараз квартирується жандармерія, а це я забрав ще позавчора, окрім цього, більше вже нічого не було.

Цінь Чжен'ї. А ти...

Сюй А’фа. (перевівши подих) Тягав воду цим японським собакам два дні поспіль, ось вони мене й відпустили!

Цінь Чжен'ї. Рис давали? Як то кажуть, худий кулі - i той рису добуде.

Сюй А’фа. Рис? Це було б непогано, та вони мою вовняну камізельку - i ту здерли.

Цянь Ціньсянь. Так що ти вирішив робити? Рису в нас теж немає, машини в пана вже так само немає, ти...

Сюй А'фа. Я вирішив повернутися.

Цінь Чжен’ї. Повернутися? Куди?

\section{Шиизуку виносить глечик з водою.}

Сюй А'фа. Повернуся в Кантон.

Цянь Ціньсянь. А зараз небезпечно їхати?

Сюй А'фа. Поїду кружним шляхом, разом з декількома своїми друзями. А ви $з$ паном що вирішили?

Цянь Ціньсянь мовчить. 
Цінь Чжен'ї. (cidaє) Ми, на жаль, не можемо поїхати, як вони, на дорогах безліч грабіжників, японських солдатів...

Сюй А'фа. Ну добре, я тоді пішов, а ви не виходьте на вулицю - там багато японської солдатні.

\section{Цянь Ціньсянь покивала головою.}

Сюй А’фа. (дійшовши до дверей, наче щось згадав) О (з кишені витягає в'язку ключів), це ключі від машини.

Цянь Ціньсянь. (гірко посміхаючись) Машини вже немає, який з того сенс? (Жестом показує, щзо треба їх викинути.)

Сюй А'фа. (сміється) Ну, принаймні, не дати цим японським собакам так просто ії завести (виходить).

Шицзуку. (підходить до Юй Шифу) Ох, мені здається, що тобі із Шоучжень усе ж таки краще піти до лікарні, А Мей казала...

А Мей своїми ключами відмикає двері, заходить.

А Мей. Я рис не купити.

Шицзуку. А це вже чому?

А Мей. Лише знайти борошно.

Шицзуку. Гаразд, я тоді зроблю пампушок.

A Мей виходить.

Цінь Чжен'ї. (підходить до книжкової полииі, несподівано щось згадує) Хм-м, друже Юй, це все ж книжки англійською мовою, треба їх якось прибрати, інакше японці можуть назвати тебе англофілом...

Юй Шифу. Як прибрати?

Цінь Чжен'ї. Спалити, нам треба триматися разом, а книжки... Потім можна буде купити.

Юй Шифу. (хитає головою) Ні, ці книжки й зараз купити не легко; до того ж у мене є книжки і німецькою, і японською.

Цінь Чжен'ї. (невдоволено) Книжки тут явно не до ладу, якщо в домі $є$ книжки, то відразу скажуть, що інтелігент. А інтелігентів японці зневажають, i, як на мене, то лише більше проблем буде...

Дженні. Ага, позавчора багато хто викидав книжки через вікно... Немало хороших книжок, усі вулиці були заповнені.

Цянь Юй. (щиро посміхаючись) Усе правильно, пане Юю, коли людям не дозволяють читати книжки, а інтелігенції плюють в обличчя, то це характерна особливість фашистської бацили.

Дженні. (підіймається, упорядковуючи свій одяг) Ну гаразд, мені треба йти. (повертає голову до Цянь Юя) Милий Цянь, а ти заходь до мене в гості.

Шицзуку. Нi, міс Ма, так не можна, на вулиці лихих людей без ліку.

Дженні. (знизуючи плечима) Але ж і тут не цілком безпечно.

Цянь Юй. Може, краще все ж таки перевдягнутися? 
Шицзуку. (сердечно та ввічливо) Не йди: коли всі разом, якось сміливіше. Якщо вже справді вирішила піти, тоді треба вичекати час... Коли на вулицях не буде солдатів, я відправлю А Мей провести тебе, гаразд?

Дженні, посміхаючись, хитає головою. Коли вона вже зібралася виходити, до неї підходить Цянь Юй.

Цянь Юй. (закохано) Не йди, ти...

Дженні. Нi, (передумавщи) тоді ти...

Шиизуку, яка стояла весь час біля вікна, переполошено підбігає до мами, мовчки тягне ї̈ до вікна.

Шицзуку. Ну що там, га?

Оскаженілий стукіт у двері. Усі стоять налякані. Цінь Чжен'ї потроху просувається до внутрішніх покоїв.

Стукіт у двері стає ще лютішим.

Цянь Юй підходить до дверей, відсунувши фіранку, дивиться у віконие.

Миттю міняється з виду, жестом руки показує всім хутчіше сховатися.

Шиизуку, Дженні та Шоучжень швидко заходять до вбиральні. Чжао

Аньтао прокинувся, його вигляд свідчить про те, щчо він одразу зрозумів, у чім справа, прудко штовхає Цянь Ціньсянь сховатися.

Цянь Юй відчиняє двері. Заходять троє японських мародерів із гвинтівками, наведеними на всіх присутніх, одразу мовчки починають общукувати одяг кожного. Японський солдат один відбирає в Цянь Юя кулькову авторучку, японський солдат два забирає в Юй Шифу старовинний кишеньковий годинник, японський солдат три віднімає у Чжао Аньтао наручний годинник

і вімає собі на руку, де вже висить три таких. Японський солдат один піднімає губну гармошку Шоучжень, проте, свиснувши пару разів, відкидає.

Японський солдат один. (до Цінь Чжен'i) Tabako (тютюн) є?

Цінь Чжен '̈̈, прудко діставши з кишень та ящиків увесь тютюн, віддає йому. Японські солдати окинули поглядом кімнату, уже зібралися виходити, але раптом їхні погляди привернули пробірки і медичне приладдя на столі. Вони розвертаються й підходять подивитися.

Японський солдат два. Nani, ishakana? (Що, лікар?) (Одним махом змітає зі столу пробірки, склянки тощзо.)

Юй Шифу. (побачивщи, щео склянки з культивованими ним бацилами перекинулися, стрілою кидається зупинити його) Це ж, це ж...

Японський солдат два. (обурено) Nani! (Що!) (рукою штовхає Юй Шифу на стільчик, пробірки кидає на підлогу, розвернувшись, кровожерливо дивиться на нього) Naka naka erasona kao o shiteruna. (Виглядає на диво непогано.) (Побачивши прикро обурений вираз обличчя Юй Шифу, несподівано б'є його по щчочі, знущаючись та насміхаючись, тягне його за бороду.) Ха-ха-ха... 
Японський солдат один. (плюхнувшись на диван, випробовує його пружність) Sora, nakanaka kimochiga iizo! (Хa, і пахне непогано!)

Японський солдат три. (підійшовщи до дверей) Sa sankai - da! (Гаразд, ходімо на тертій поверх!)

Японський солдат два підходить до дверей. Японський солдат один несподівано бачить накритий білою полотниною мікроскоп, повертається, бере його і збирається йти. Юй Шифу робить крок уперед, заступаючи йому дорогу. Японський солдат один відштовхує його і йде далі, та Юй Шифу знову пробує його наздогнати. Стримуючись увесь час до ијєё миті, Цянь Юй не витримує, робить кілька кроків уперед, перехоплює мікроскоп і хоче поговорити з японцем.

Японський солдат один. Nani konchikusho! (Ах ти ж покидьок!) (Baлить Цянь Юя на підлогу ударом кулака, розвертається і руків'ям гвинтівки вщент розносить усе на столі та в шафі Юй Шифу; кілька разів б'є Юй Шифу ногами.)

Юй Шифу жалібно стогне та квилить.

Японські солдати далі прямують до виходу. Почувши голос Юй Шифу, Шиизуку відчиняє двері й вилітає, наче навіжена. Допомігши Юй Шифу підвестися, дивиться на японських солдатів, хоче щзось сказати, але замовкає, стримавши все в собі, гірко дивиться.

Японський солдат два, розвернувшись, дивиться на Шицзуку, на його обличчі з'являсться мерзенна посмішка, він рукою пестливо проводить по ї̈ щоці. Шицзуку, зиіпивщи зуби, відкидає його руку. Цянь Юй прудко підводиться, заступивши Шиизуку. Японський солдат чимдуж відштовхує його, проте Цянь Юй щзосили намагається протистояти йому.

Японський солдат два. Koitsu fute-ja! (Цей хлопець якось хитко стоїть на ногах!) (Волочить його, вони починають вовтузитися.)

Японський солдат один. Мо yuku zo! (Ходімо!)

Японський солдат два. (обурено) Tsurete yuke! (Його із собою заберемо!)

Японський солдат два відволік Цянь Юя до дверей, японський солдат один і японський солдат три виходять. Японський солдат два щосили щтовхає Цянь Юя вперед, Цянь Юй, вочевидь, падає зі сходів, японський солдат два йде слідом за ним, виходить.

Юй Шифу, доклавши чимало зусиль, підіймається й хоче їх наздогнати, Шицзуку зупиняє його.

Чжао Аньтао підводиться, наче забувщи про все на світі, підібгає до дверей.

Юй Шифу. (піднявщи руку) Ти... Ти...

Зі сходів чути звуки лайки та боротьби. Крики болю Цянь Юя. Раптом гримають два постріли гвинтівки. Усе стихає. 
Шицзуку спантеличено підбігає до вікна, несамовито зойкнувши й рукавом затуливши обличчя, хиткою ходою відходить. Юй Шифу підтримує іï.

Усе зрозумівши з ї̈ поведінки та виразу обличчя, Чжао Аньтао швидко вибігає.

Дженні, Цянь Ціньсянь, А Мей і Шоучжень потихеньку виходять одна за одною. Застигли. Тиша.

Шицзуку раптом починає ревно плакати.

Юй Шифу. (втішаючи іï) Не треба плакати, не треба.

Шицзуку. (несамовито) Вони принизили тебе, замордували його - це вже й так важко витримати, але (чітко відокремлюючи слова) від чого мені ще гірше на серці - це від того, що я на власні очі бачила своїх співвітчизників, японців, які неприховано грабували, гвалтували, убивали й робили ці всі мерзенні справи... (перевівши подих) Я багато про що чула, та завжди сподівалася, що це неправда, але зараз, коли я побачила все... (знесилено падає).

Юй Шифу. (підтримуючи ії) А Мей, давай, відведи її прилягти.

Шоучжень. (підбігаючи) Мам...

Юй Шифу. (наче оповіщаючи) Ми їдемо, повертаємося.

Цянь Ціньсянь. (кидається до дверей) Аньтао, Аньато.

Цінь Чжен'ї. Їхати?

Юй Шифу. (наче сам до себе) Треба їхати, завжди можна поїхати.

Чжсао Аньтао заходить із тілом Цянь Юя на руках.

Усі пильно дивляться на нього.

Завіса стрімко опускається. 